\title{
Evidence for androgen receptor gene expression and growth inhibitory effect of dihydrotestosterone on human adrenocortical cells
}

\author{
R Rossi ${ }^{1}$, M C Zatelli ${ }^{1}$, A Valentini ${ }^{1}$, P Cavazzini $^{2}$, F Fallo $^{3}$, \\ L del Senno ${ }^{4}$ and $\mathbf{E}$ C degli Uberti ${ }^{1}$ \\ ${ }^{1}$ Department of Biomedical Sciences and Advanced Therapies - Section of Endocrinology, ${ }^{2}$ Istituto di Anatomia Patologica, ${ }^{4}$ Centro di Studi Biochimici delle \\ Patologie del Genoma Umano, Dipartimento di Biochimica e Biologia Molecolare, University of Ferrara, I-44100 Ferrara and ${ }^{3}$ Division of Endocrinology, \\ University of Padova, Italy \\ (Requests for offprints should be addressed to E C degli Uberti, Department of Biomedical Sciences and Advanced Therapies - Section of Endocrinology, \\ University of Ferrara, Via Savonarola 9, I-44100 Ferrara, Italy)
}

\begin{abstract}
Evidence for the expression of the canonic androgen receptor (AR) in human adrenal cortex has not been provided so far. The aim of the present study was to demonstrate the expression of the AR gene in normal and neoplastic adrenocortical human tissues and in the human adrenocortical cancer cell line, NCI-H295, and then to evaluate the effect of dihydrotestosterone (DHT) on human adrenocortical cell growth. An AR cDNA fragment with the expected size of $262 \mathrm{bp}$ was detected by using reverse transcription (RT)-PCR in normal and neoplastic adrenocortical human tissues and in the neoplastic cell line, demonstrating that the gene for $\mathrm{AR}$ is indeed expressed in human adrenal cells.

In the human adrenocortical cancer cell line NCI-H295, DHT at physiological concentrations
\end{abstract}

produced a significant reduction in cell proliferation and inhibition of colony formation in soft agar. The inhibitory effect on adrenocortical cell growth was evident after both 24 and $48 \mathrm{~h}$ of treatment. The antiandrogens, cyproterone acetate and hydroxyflutamide, were capable of reversing the effects exerted by DHT. The androgen-induced growth inhibitory effect was also detected in primary culture of three non-functioning adrenocortical adenomas.

These findings show that the canonic AR is present in human adrenocortical cells and that androgens may have a role in the adrenal cortex by reducing cell proliferation.

Journal of Endocrinology (1998) 159, 373-380

\section{Introduction}

Androgens exert a variety of effects upon mammalian tissues by controlling cellular growth and differentiation through a stereospecific high-affinity intracellular receptor and modification of gene expression (Mooradian et al. 1987, Berger \& Watson 1989). Whereas androgenic effects associated with differentiation of the male phenotype occur in reproductive tract tissues, anabolic effects occur within non-reproductive tissues such as liver, kidney and muscle (Berger \& Watson 1989).

Androgen receptor (AR) has been identified in the adrenal cortex of immature and adult Rhesus monkeys by immunocytochemistry (Hirst et al. 1992) and in adrenocortical tissue of adult rat by immunoblot assay (Bentvelsen et al. 1996). Furthermore, testosterone has been shown to reduce adrenal weight in castrated male rats (Rifka et al. 1978). These data, taken together, suggest that androgens can influence adrenocortical growth and function by a mechanism involving receptor-mediated pathways.
The aim of the present work was to investigate the expression of AR RNA in normal and neoplastic adrenocortical human tissues and in a human adrenocortical cancer cell line, NCI-H295. We also studied the effect of dihydrotestosterone (DHT) on human adrenocortical cell growth, assessing the response of these cells to androgens in terms of morphology and growth properties.

In order to examine whether the action of DHT on human adrenocortical cell growth is mediated by the androgen receptor, we attempted to antagonize it by the antiandrogens, cyproterone acetate and hydroxyflutamide.

\section{Materials and Methods}

\section{Collection of adrenocortical tissues}

Normal and neoplastic adrenocortical tissues were obtained from female and male patients undergoing surgery for functioning and non-functioning adrenocortical adenomas. No patient was receiving androgenic or steroid 
treatment. Eleven benign tumours, including five nonfunctioning adenomas, four cortisol- and two aldosteroneproducing adenomas were studied. Normal adrenal tissue was obtained from apparently normal areas of glands from patients undergoing surgery for non-functioning adenoma. After surgery, tissues were immediately frozen in liquid nitrogen under sterile conditions, stored at $-80{ }^{\circ} \mathrm{C}$ until they underwent RNA extraction, and then pulverized by a tissue dismembrator (Mikro-Dismembrator II, B Braun, Melsungen, Germany). For primary culture experiments, adrenocortical tissue samples were collected under sterile conditions in RPMI 1640 medium (without phenol red, with L-glutamine; Serva Feinbiochemica, Heidelberg, Germany) and processed within $30 \mathrm{~min}$.

\section{NCI-H295 cell line culture}

Human NCI-H295 adrenocortical tumour cells were obtained from the American Type Culture Collection (Rockville, MD, USA). Cells were maintained in complete RPMI 1640 medium (without phenol red and with L-glutamine; Serva Feinbiochemica) supplemented with $2 \%$ foetal calf serum (FCS; Mascia Brunelli, Milan, Italy), and containing sodium selenite $(1 \mathrm{ng} / \mathrm{ml}$, Sigma, St Louis, MO, USA), insulin $(5 \mu \mathrm{g} / \mathrm{ml}$, Novo Nordisk, Princeton, USA), transferrin $(5 \mu \mathrm{g} / \mathrm{ml}$, Sigma), dexamethasone $\left(10^{-8} \mathrm{M}\right.$, Sigma), $17-\beta$-oestradiol $\left(10^{-8} \mathrm{M}\right.$, Sigma), $100 \mathrm{U} / \mathrm{ml}$ penicillin and $0 \cdot 1 \mathrm{mg} / \mathrm{ml}$ streptomycin (Mascia Brunelli), $100 \mu \mathrm{g} / \mathrm{ml}$ amphotericine (Squibb, New York, USA) at $37^{\circ} \mathrm{C}$ in a humified atmosphere of $5 \% \mathrm{CO}_{2}$ and $95 \%$ air. To eliminate the influence of steroid hormones in the medium, in the hormone induction experiments, cells were switched to RPMI 1640 medium supplemented with $2 \%$ charcoal (1\%)-dextran $(0 \cdot 1 \%)$ treated FCS (CDT-FCS), sodium selenite $(1 \mathrm{ng} / \mathrm{ml})$, insulin $(5 \mu \mathrm{g} / \mathrm{ml})$, transferrin $(5 \mu \mathrm{g} / \mathrm{ml})$, and antibiotics 3 days before incubation with DHT (Sigma) alone, or with cyproterone acetate or hydroxyflutamide (ScheringPlough, Milan, Italy) alone, or DHT with one of these antiandrogens.

\section{Growth curve studies}

NCI-H295 cells $\left(5-7 \times 10^{4}\right.$ cells/well $)$ were plated in 24-multi-well plates (Falcon, Lincoln Park, NJ, USA). After overnight growth, cells were incubated in the absence or presence of DHT at concentrations ranging from $10^{-14} \mathrm{M}$ to $10^{-8} \mathrm{M}$ in medium without steroids and supplemented with $2 \%$ CDT-FCS. Cells were also tested with and without antiandrogens $\left(10^{-8} \mathrm{M}\right.$ cyproterone acetate and $10^{-8} \mathrm{M}$ hydroxyflutamide), with and without DHT. After a 24- or 48-h treatment, cells were harvested by trypsinization and counted using a haemocytometer in 12 different experiments. All experiments were carried out in quadruplicate. DHT, cyproterone acetate and hydroxyflutamide were added to the medium in alcohol solution with a final concentration of ethanol $<0 \cdot 1 \%$ in both control and hormone-treated cultures. Viability of NCI-H295 cells was determined by tripan blue staining and the number of viable cells was always in the range $85-95 \%$.

\section{Primary culture of human adrenocortical cells}

After surgical removal of three non-functioning adrenocortical adenomas, the tissue was finely minced with scissors and cells were dispersed by a collagenase digestion $(1 \mathrm{mg} / \mathrm{ml})$ in $6 \mathrm{ml}$ complete RPMI 1640 medium as for NCI-H295 cells. The cell suspension was centrifuged at $250 \mathrm{~g}$ for $5 \mathrm{~min}$ and the cell pellet washed twice and then filtered through a double layer of nylon gauze (300 mesh). Cells were then seeded in monolayer cultures in 24-multiwell plates (Falcon) and grown in complete medium at $37^{\circ} \mathrm{C}$ in a humidified atmosphere of $5 \% \mathrm{CO}_{2}-95 \%$ air. After $24 \mathrm{~h}$, the medium was replaced with fresh medium without steroids and with CDT-FCS. In this defined medium, treatment with $10^{-11} \mathrm{M}$ DHT was performed, starting on day 3 of culture, and after $24 \mathrm{~h}$ of treatment the cells were harvested by trypsinization and counted using a haemocytometer. Each experiment was done in quadruplicate.

\section{Isolation of RNA}

Pulverized adrenocortical tissues and cultured carcinoma cells were lysed in guanidium isothiocyanate, and total RNA was purified by phenol-chloroform extraction and isopropanol-ethanol precipitation (RNAzol B solution, Biotech Lab Inc., Houston, TX, USA). To prevent further DNA contamination, RNA was treated for $5 \mathrm{~min}$ at $37^{\circ} \mathrm{C}$ with RNAse-free DNAse and, after $10 \mathrm{~min}$ at $70^{\circ} \mathrm{C}$, it was again phenol-chlorophorm extracted. The amount of RNA was determined by optical density at $260 \mathrm{~nm}$.

\section{RT-PCR}

Using 1st Strand cDNA Synthesis Kit (Boehringer, Mannheim, Germany), $1 \mu \mathrm{g}$ total RNA from cultured cells and adrenocortical tissues was reverse-transcribed at $25{ }^{\circ} \mathrm{C}$ for $10 \mathrm{~min}$ and then at $42{ }^{\circ} \mathrm{C}$ for $60 \mathrm{~min}$ in a $20-\mu \mathrm{l}$ solution containing $20 \mathrm{U}$ AMV Reverse Transcriptase, $50 \mathrm{U}$ RNAse inhibitor and 100 pmol AR reverse primer. cDNA product (4 $\mu \mathrm{l} \mathrm{RT}$ reaction) was amplified with $1 \mathrm{U}$ Thermo aquaticus (Taq) polymerase (Boehringer) and $100 \mathrm{pmol}$ reverse and forward primers in $25 \mu \mathrm{l}$ reaction mixture containing $200 \mu \mathrm{mol} \mathrm{dNTPs,} 50 \mathrm{mmol} \mathrm{KCl}$, $1 \mathrm{mmol} \mathrm{MgCl}_{2}, 0 \cdot 01 \%$ gelatin and $0 \cdot 1 \%$ Triton X-100. The PCR reaction was performed under mineral oil for 30 cycles of amplification. Each cycle consisted of $94^{\circ} \mathrm{C}$ for $60 \mathrm{~s}, 55^{\circ} \mathrm{C}$ for $60 \mathrm{~s}, 72{ }^{\circ} \mathrm{C}$ for $60 \mathrm{~s}$. After the last cycle, samples were incubated for an additional $10 \mathrm{~min}$ at $72{ }^{\circ} \mathrm{C}$ 
to ensure that the final extension step was complete. The cycling reaction was performed in the DNA thermal cycler from Violet.

Oligonucleotide primers used for AR cDNA were 5'GTGGATGGGCTGAAAATC3' (sense) and 5'AG ATCATCTCTGTGCAAGT3' (antisense). These are located in exons 7 and 8 of the human AR gene and are expected to amplify an AR cDNA fragment of $262 \mathrm{bp}$ in size. The nucleotide sequence corresponds to the C-terminal sequence of the protein in the hormone binding domain.

After amplification, PCR products were electrophoresed in $2 \%$ agarose gel and stained with ethidium bromide.

\section{Northern blot analysis and probe labelling}

RNA from tissues and cultured adrenocortical carcinoma cells were separated onto denaturing agarose gel, stained with ethidium bromide, transferred to a Gene Screen Plus Filter (NEN, Dupont, Boston, MA, USA) and hybridized essentially as described previously (degli Uberti et al. 1991, Sambrook et al. 1989). Human AR and GAPDH cDNA plasmids were ${ }^{32} \mathrm{P}-$ labelled by the Random Primed DNA labelling kit (Boehringer). Filters were then exposed to $\mathrm{X}$ OMAT films at $-80^{\circ} \mathrm{C}$ with Dupont intensifying screens. The levels of AR and GAPDH mRNA in each sample were measured using densitometric analysis of the autoradiographic signals.

\section{Immunocytochemistry}

In order to visualize the AR protein in adrenocortical carcinoma cell lines, the monoclonal mouse antibody F39.4.1, directed against a fragment of the N-terminal domain of the androgen receptor (aminoacids 301-320) was used, as previously decribed (Rossi et al. 1996a).

NCI-H295 cells were grown in monolayer (approximately $10^{5}$ cells/well) for $24 \mathrm{~h}$ in chamber slides (Nunc Inc., Naperville, IL, USA) in 2\% CDT-FCS medium and then incubated with and without $10^{-11} \mathrm{M}$ DHT. After $24 \mathrm{~h}$, cells were washed in saline and, after removal from chamber, were fixed in $3.7 \%$ paraformaldehyde for $10 \mathrm{~min}$, rinsed in PBS and transferred to cold methanol and acetone $\left(-20^{\circ} \mathrm{C}\right)$ for 3 and $5 \mathrm{~min}$, respectively. After rinsing in PBS, slides were stored at $-20{ }^{\circ} \mathrm{C}$ until required for immunostaining. The antibody was used at $1: 200$ dilution in PBS. The avidin-biotin detection system was used. All the antisera (normal serum, biotinylated antibody against the primary antibody with $40 \%$ normal human serum, and avidin-biotinylated horseradish peroxidase complex) were supplied by commercial kit (Vector Laboratories Inc., Burlingame, CA, USA).

\section{Assay for anchorage-independent growth}

Agar (Difco) was suspended in water to a final concentration of $2 \%$, autoclaved, and cooled to $50{ }^{\circ} \mathrm{C}$. This agar solution $(330 \mu \mathrm{l})$ was added to twofold concentrated CDT-FCS medium $(1 \mathrm{ml})$ with the hormonal treatment, to make a final volume of $2 \mathrm{ml} /$ well and an agar concentration of $0 \cdot 6 \%$. Trypsinized NCI-H295 cells were counted and $2 \times 10^{5}$ cells were suspended in $50 \mu \mathrm{l}$ and added to each agar solution (containing hormonal treatment) and immediately poured into 6-multi-well plates. After 10 days of incubation, colonies of more than $100 \mu \mathrm{m}$ in diameter were randomly scored in triplicate.

\section{Statistical analysis}

Data are expressed as the mean \pm S.E.M. Statistical analysis of the data was performed using the unpaired and paired Student's $t$-test and the non parametric Wilcoxon's test, as appropriate.

\section{Results}

\section{AR RNA in human adrenocortical cells and tissues}

Figure 1 shows the presence of AR RNA in human adrenocortical tissues and in the adrenocortical carcinoma cell line NCI-H295. RT-PCR analysis (Fig. 1a), revealed a band with the expected size of $262 \mathrm{bp}$ in normal and adenomatous adrenocortical tissues, and in hyperplastic prostate and in the AR cDNA plasmid, which were included as positive controls. This band was also detected in the adrenocortical carcinoma cell line, NCI-H295, incubated for $24 \mathrm{~h}$ in medium supplemented with $2 \%$ FCS. Because primers were derived from sequences of exons 7 and 8 of AR cDNA, this band was not the result of genomic contamination. AR RNA transcripts revealed by RT-PCR analysis were also studied by Northern blot analysis. As indicated in Fig. 1b, a signal of approximately $11 \mathrm{~kb}$, as expected for the AR mRNA (Lubahn et al. 1988, Faber et al. 1991), was detected by hybridization with AR cDNA probe in RNA isolated from adrenocortical tissues.

\section{Detection of AR protein in human adrenocortical carcinoma cells}

Figure 2 shows immunocytochemistry staining for AR protein in NCI-H295 cells grown in the absence and presence of $10^{-11} \mathrm{M}$ DHT, using the monoclonal antibody, F39.4.1. In untreated cells, weak staining was present in the cytoplasm and in the nucleus, with few strongly positive nuclei. In androgen-treated cells, the number of positive nuclei markedly increased. No immunostaining was observed when the primary antibody was replaced by diluent or by non-immune serum.

\section{Effect of DHT on NCI-H295 cell growth}

Figure 3 shows the effect of androgen on the growth of NCI-H295 cells. DHT significantly $(P<0 \cdot 05)$ reduced 
(a)

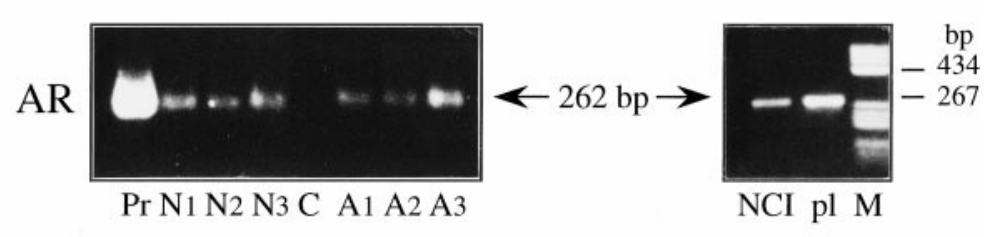

(b)

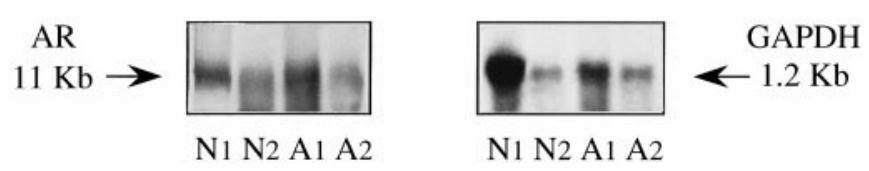

Figure 1 AR RNA in human adrenocortical tissues and in the human adrenocortical carcinoma cell line NCl-H295. (a) RT-PCR products obtained from RNA of three normal $(\mathrm{N} 1-\mathrm{N} 3)$ and three adenomatous (A1-A3) adrenocortical tissues and from the human adrenocortical carcinoma cell line, $\mathrm{NCl}-\mathrm{H} 295(\mathrm{NCl})$. A hyperplastic prostate $(\mathrm{Pr})$ and the AR cDNA plasmid (pl) are included as positive controls. A molecular size DNA marker (M) and an AR-specific fragment of $262 \mathrm{bp}$ in size, predicted by the AR cDNA plasmid sequence (pl) are indicated. RNA was isolated and reversed with an AR reverse primer, as described in Materials and Methods. Aliquots of RT reaction mixtures were amplified with AR primers, separated in agarose gel and analysed by u.v. examination. The unlabelled well (C) represents the negative control and contains the reaction product without the cDNA. (b) Northern blot analysis of total RNA isolated from two normal (N1, N2) and two adenomatous (A1, A2) adrenocortical tissues. RNA was denaturated with formaldehyde, fractionated in denaturing agarose gel, analysed by blot hybridization with ${ }^{32} \mathrm{P}$-labelled AR and GAPDH cDNA plasmid, as described in the Methods section.

cell proliferation at concentrations ranging from $10^{-12}$ to $10^{-8} \mathrm{M}$, with a $49 \cdot 56 \pm 14 \cdot 8 \%$ mean inhibition after $24 \mathrm{~h}$ of treatment and with a $51 \cdot 2 \pm 5 \cdot 5 \%$ mean inhibition after $48 \mathrm{~h}$ of treatment. The greatest inhibition of growth was apparent with DHT $10^{-9} \mathrm{M}(P<0 \cdot 01)$ after $24 \mathrm{~h}$ of treatment. Testosterone reduced NCI-H295 cell prolifer- ation by the same rate and to the same degree of significance as was found for DHT (data not shown).

After $24 \mathrm{~h}$ treatment, the antiandrogen, cyproterone acetate, $10^{-8} \mathrm{M}$ did not change NCI-H295 cell growth, but was capable of reversing the androgen-induced inhibition of proliferation (Fig. 4A). Comparable results were
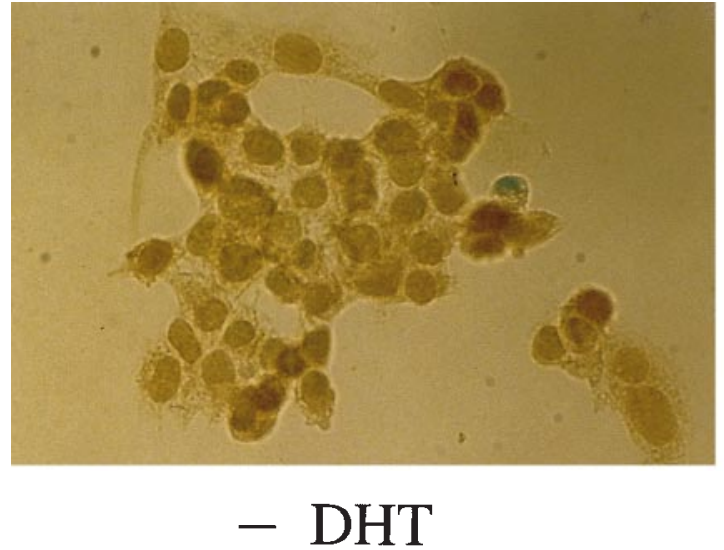

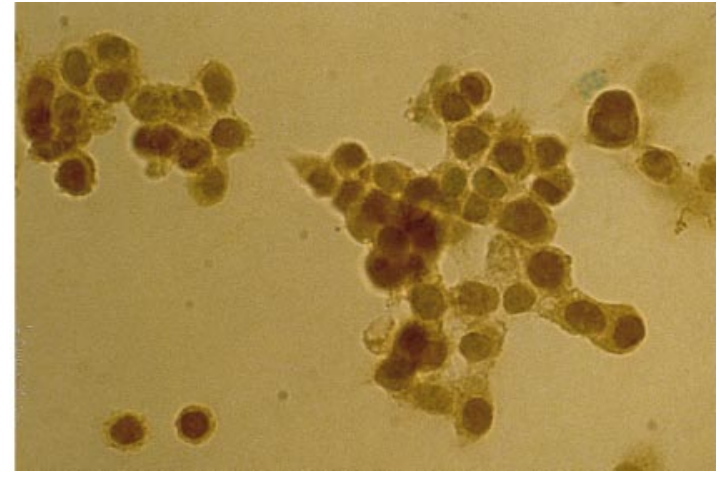

+ DHT

Figure 2 Visualization of AR protein in the human adrenocortical carcinoma cell line, $\mathrm{NCl}-\mathrm{H} 295$. Cells were grown for $24 \mathrm{~h}$ on a chamber glass slide and cultured in the absence (- DHT) or presence of $10^{-11} \mathrm{M} \mathrm{DHT}$ (+ DHT). Cells were immunostained for AR with monoclonal antibody F39.4.1 and visualized by the indirect conjugated peroxidase technique using methyl green for nuclear counterstaining, as described in Materials and Methods. Original magnification, $\times 400$. 


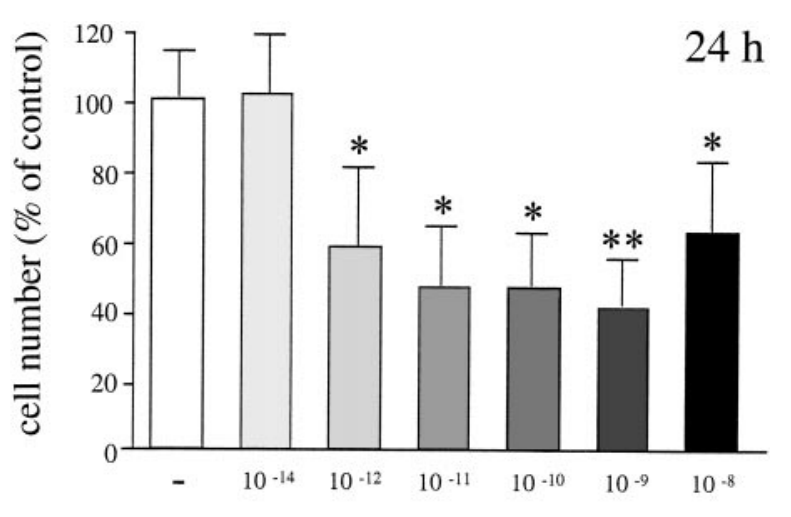

DHT (M)

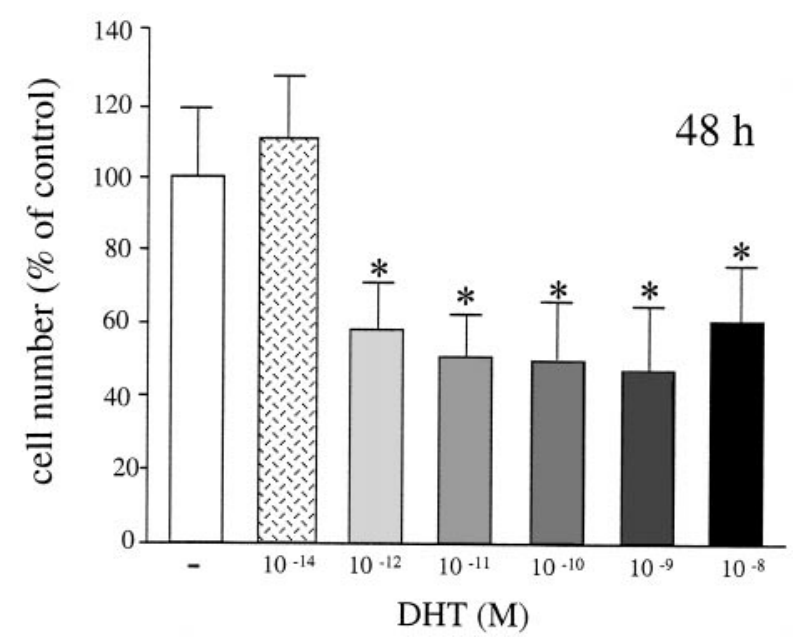

Figure 3 Effect of DHT on $\mathrm{NCl}-\mathrm{H} 295$ cell growth: number of $\mathrm{NCl}-\mathrm{H} 295$ cells grown for 24 and $48 \mathrm{~h}$ without $(-)$ and with DHT at concentration ranging from $10^{-14}$ to $10^{-8} \mathrm{M}$. Cells were seeded at approximately $6 \times 10^{4}$ per well in 24 -multi-well plates, cultured for 24 or $48 \mathrm{~h}$ with and without DHT and then collected and counted in a cell counter. The mean values \pm S.E.M. in hormone-treated cells were compared with those of untreated cells and expressed as a percentage of control values in at least 12 independent experiments in quadruplicate. ${ }^{*} P<0 \cdot 05,{ }^{*} P<0 \cdot 01$, compared with untreated cells.

obtained using $10^{-8} \mathrm{M}$ hydroxyflutamide (Fig. 4B), which was capable of reversing the growth inhibition induced by $10^{-9}$ and $10^{-11} \mathrm{M}$ DHT.

Effect of DHT on growth of human adrenocortical cells in primary culture

The effect of androgen on human adrenocortical cell proliferation in primary culture was also tested. After $24 \mathrm{~h}$ incubation with $10^{-11} \mathrm{M} \mathrm{DHT}$, a significant inhibition of

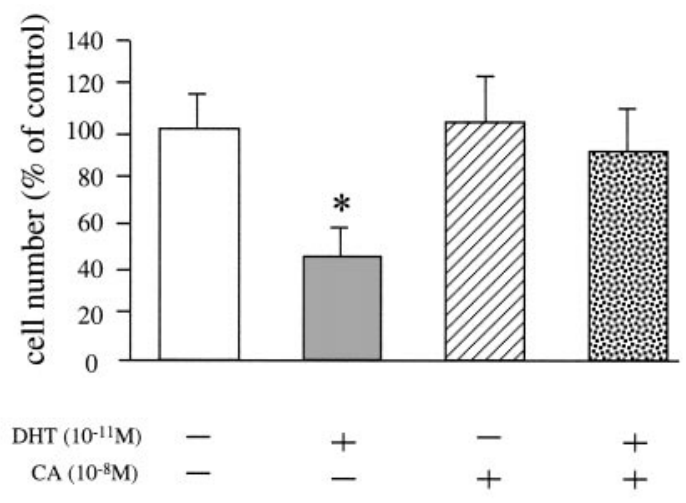

(A)

(B)

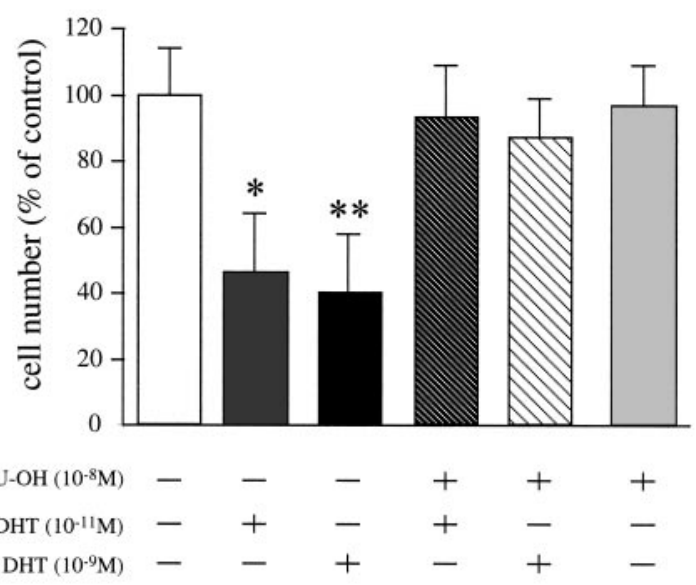

Figure 4 Effect of cyproterone acetate (CA) and hydroxyflutamide (Flu-OH) on $\mathrm{NCl}-\mathrm{H} 295$ cell growth. (A) Cell number in samples of $\mathrm{NCl}-\mathrm{H} 295$ cells grown for $24 \mathrm{~h}$ with and without DHT $\left(10^{-11} \mathrm{M}\right)$, in the absence and presence of $\mathrm{CA}\left(10^{-8} \mathrm{M}\right)$. The mean values \pm S.E.M. in hormone-treated cells were compared with those of untreated cells and expressed as a percentage of control values in at least six independent determinations. ${ }^{*} P<0 \cdot 05$ compared with untreated cells. (B) Cell number in samples of NCl-H295 cells grown for $24 \mathrm{~h}$ with and without DHT $\left(10^{-11}\right.$ and $\left.10^{-9} \mathrm{M}\right)$, in the absence and presence of Flu-OH $\left(10^{-8} \mathrm{M}\right)$. The mean values \pm S.E.M. in hormone-treated cells were compared with those of untreated cells and expressed as a percentage of control values in at least six independent determinations. ${ }^{*} P<0 \cdot 05,{ }^{* *} P<0 \cdot 01$, compared with untreated cells.

cell growth was found in three different experiments, with a mean percentage inhibition of $26.5 \%$ compared with control cells $(P<0 \cdot 05)$.

\section{Anchorage-independent growth inhibition by DHT}

Figure 5 shows the effect of DHT on anchorageindependent growth of NCI-H295 cells. After a 10-day period of growth, control cells formed large colonies in soft 


\section{Control}
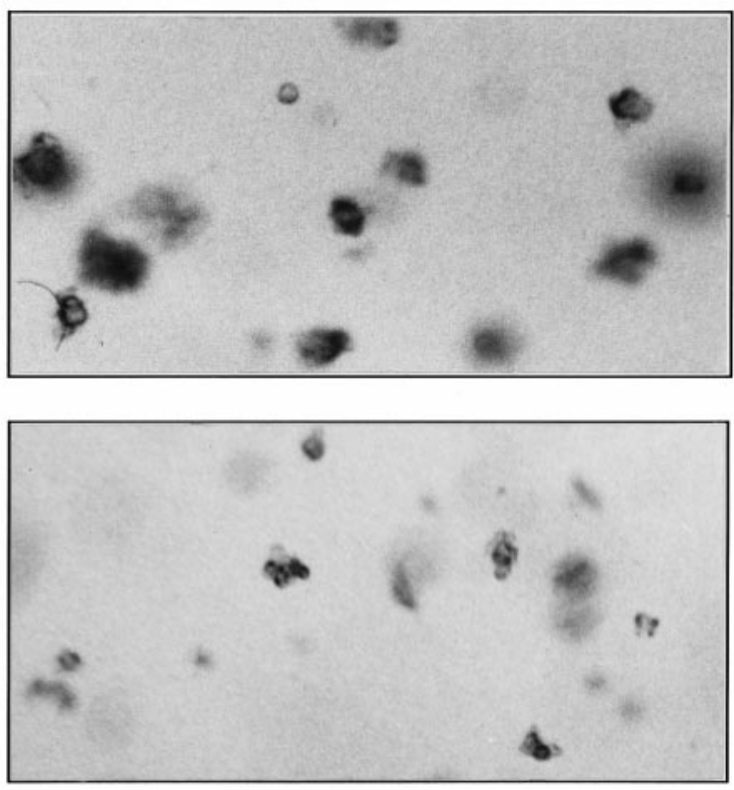

\section{+ DHT}

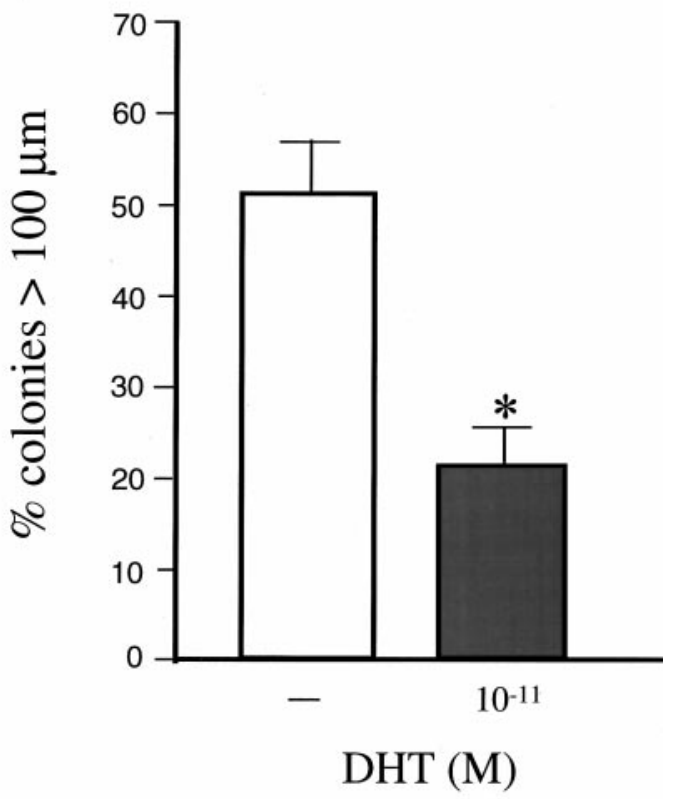

Figure 5 Effect of DHT on anchorage-independent growth of $\mathrm{NCl}-\mathrm{H} 295$ cells. The percentage of colonies greater than $100 \mu \mathrm{m}$ in diameter was determined after 10 days of growth in soft agar without hormones (control) and in the presence of $10^{-11} \mathrm{M}$ DHT $(+\mathrm{DHT})$ in six independent experiments. ${ }^{*} P<0 \cdot 01$ compared with untreated cells. Original magnification, $\times 100$.

agar whereas, in the presence of $10^{-11} \mathrm{M}$ DHT, the growth potential of NCI-H295 cells was consistently reduced. In control samples, $50 \cdot 3 \%$ of colonies showed a diameter greater than $100 \mu \mathrm{m}$. In presence of androgen, colonies were less dense and only $21.9 \%$ of them reached a size greater than $100 \mu \mathrm{m}(P<0 \cdot 01)$. Cyproterone acetate again counteracted the DHT-induced reduction of anchorage-independent growth (data not shown).

\section{Discussion}

In the present study, we have demonstrated the presence of the canonic AR RNA in human adrenocortical tissues, indicating that the gene for $\mathrm{AR}$ is, indeed, expressed in human adrenal cortex. AR expression has been confirmed in the human adrenocortical cancer cell line, NCI-H295, in which the AR protein has also been demonstrated by the use of a specific monoclonal antibody, F39.4.1 (Lubahn et al. 1988). These observations are in accordance with previously reported findings in other mammalian adrenal tissues. A relatively high level of a specific highaffinity androgen-binding protein (Calandra et al. 1978, Rifka et al. 1978) has been previously determined by ligand-binding assays in the adrenal gland of rodents. More recently, the presence of AR protein has been demon- strated, by immunocytochemistry and immunoblot, in the adrenal gland of the Rhesus monkey (Hirst et al. 1992) and rat (Bentvelsen et al. 1996). However, different observations were made by Ruizeveld de Winter et al. (1991) who were unable to visualize AR protein in human adrenal specimens using the monoclonal antibody F39.4.1. Such a finding may reflect a level of AR that was too low to be detected immunohistochemically in this tissue.

The increase in nuclear AR positivity induced by androgen treatment is consistent with the nuclear localization of the receptor in the human cells. Similarly, previous results (Husmann et al. 1990, Sar et al. 1990) have shown that, in rat ventral prostate and epididymis, nuclear immunostaining of AR that is lost after castration rapidly recovers after injection of androgen. These authors have suggested that the androgen-free receptor undergoes a marked increase in immunoreactivity after hormone binding or receptor stabilization, as later proposed by Kemppainen et al. (1992). In addition, Jenster et al. (1992), studying the relationships between various structural domains and their different functions in the AR protein, showed that, in the absence of ligand, the wild-type AR expressed in COS-1 cells was distributed over nucleus and cytoplasm, and that the addition of hormone directed all ARs to the nucleus. 
Although the action of sex steroid hormones in the adrenal cortex is not entirely clear, it is well known that androgens influence adrenal function, morphology and steroidogenesis. Experimental data have shown that androgen treatment induces an atrophic effect in male rat adrenal cortex, and a trophic action on the zona reticularis in female guinea pigs (Toscano et al. 1990).

To date, the mechanism of action of androgen on human adrenocortical growth and differentiation is not well defined. In agreement with previous data from Rifka et al. (1978), who demonstrated an androgen-induced decrease in rat adrenal weight, our results show that DHT is capable of reducing adrenocortical adenoma and carcinoma cell proliferation. These findings, together with the androgen-induced reduction of colony formation in the NCI-H295 cell line, provide evidence for an inhibitory role of androgen on the growth of the human adrenocortical gland. The inhibitory effect of DHT that we observed with doses ranging from $10^{-12}$ to $10^{-8} \mathrm{M}$ was not associated with any induction of a cytotoxic action, as demonstrated by tripan blue staining, and was counteracted by preadministration of both the antiandrogens, cyproterone acetate and hydroxyflutamide. Hydroxyflutamide, in particular, is a pure antiandrogen because, unlike cyproterone acetate, it fails to promote AR dimerization and DNA binding, and lacks any agonistic activity (Wong et al. 1993). As neither of these androgens affected the NCI-H295 proliferation rate, but both blocked DHTinduced growth inhibition, we conclude that androgen, in our model, acts by binding its receptor. These results, together with the finding that human adrenocortical cells express the canonic AR gene at RNA and protein level, are consistent with the concept that androgens may act on the human adrenal gland by a receptor-mediated mechanism.

It is well known that sex steroid receptors have an important role in the control of the proliferation of sex steroid target cells and, in agreement with our results, several studies have shown that physiological doses of synthetic androgens, via interaction with AR, inhibit cell proliferation, colony formation in soft agar, and c-myc RNA levels in the LNCaP prostate cancer cell line (Wolf et al. 1991). Recent data have also demonstrated an AR-mediated androgen-induced inhibition of cell proliferation in the MCF7 cell line transfected with a full human androgen receptor vector (Szelei et al. 1997). In addition, we have recently demonstrated that androgens, via the canonic androgen receptor, reduce cell proliferation of human thyroid follicular cells (Rossi et al. $1996 a, b)$.

DHT may regulate human adrenocortical cell growth via an AR-mediated mechanism, by influencing the expression of genes involved in cell proliferation; however, in the human adrenal gland, the signal transduction pathway from androgen binding to the ultimate cellular response currently remains to be elucidated. Androgen may act on target cells by an autocrine or paracrine mechanism, or may modulate the sensitivity of androgenresponsive cells to stimulatory and inhibitory growth factors. We cannot exclude the possibility that, in the adrenal gland as was observed in the LNCaP cell line, DHT may increase the endogenous level of TGF- $\beta 1$ (Kim et al. 1996), which can interfere with the stimulatory effect of autocrine growth factors such as epidermal growth factor and basic fibroblast growth factor (Schuumans et al. 1988, Kasser et al. 1995).

In conclusion, our results demonstrate that DHT may induce an inhibitory effect on the growth of the human adrenocortical gland. However, further studies will be required, first to elucidate the exact mechanism of action of DHT on adrenocortical cell growth and, secondly, to investigate a potential role of androgens or their analogues in the treatment of AR-positive adrenocortical carcinomas.

\section{Acknowledgements}

This work was supported by MURST (40-60\%), CNR Italy No. 97.04455, ACRO, AIRC and by Associazione Ferrarese dell'Ipertensione Arteriosa. We thank Dr Brinkmann (Rotterdam) for the AR antibody.

\section{References}

Bentvelsen FM, McPhaul MJ, Wilson CM, Wilson JD \& George FW 1996 Regulation of immunoreactive androgen receptor in the adrenal gland of the adult rat. Endocrinology 137 2659-2663.

Berger FG \& Watson G 1989 Androgen regulated gene expression. Annual Review of Physiology 51 51-65.

Calandra V, Purvis K, Naess O, Attramadal A, Djoseland O \& Hansson V 1978 Androgen receptor in the rat adrenal gland. Journal of Steroid Biochemistry 9 1009-1015.

Faber PW, Van Rooij HCJ, Van der Korput HA, Baarends WM, Brinkmann AO, Grootegoed JA \& Trapman J 1991 Characterization of the human androgen receptor transcription unit. Journal of Biological Chemistry 266 10743-10749.

Hirst JJ, West NB, Brenner RM \& Novy MJ 1992 Steroid hormone receptors in the adrenal glands of fetal and adult rhesus monkeys. Journal of Clinical Endocrinology and Metabolism 75 308-314.

Husmann DA, Wilson CM, McPhaul MJ, Tilley WD \& Wilson JD 1990 Antipeptide antibodies to two distinct regions of the androgen receptor localize the receptor protein to the nuclei of target cells in the rat and human prostate. Endocrinology 126 2359-2368.

Jenster G, van der Corput JA, Trapman J \& Brinkmann AO 1992 Functional domains of the human androgen receptor. Journal of Steroid Biochemistry and Molecular Biology 41 671-675.

Kasser A, Kozlowski JM \& Lee C 1995 Role of basic fibroblast growth factor in autocrine regulation of $\mathrm{LNCaP}$ proliferation induced by dihydrotestosterone. Program of the 77 th Annual Meeting of The Endocrine Society, Washington DC, p 272 (Abstract 1-639).

Kemppainen JA, Lane MV, Sar M \& Wilson EM 1992 Androgen receptor phosphorylation, turnover, nuclear transport and transcriptional activation. Specificity for steroids and antihormones. Journal of Biological Chemistry 267 968-974.

Kim IY, Kim JH, Zelner DJ, Ahn HJ, Sensibar JA \& Lee C 1996 Transforming growth factor $\beta 1$ is a mediator of androgen-regulated growth arrest in an androgen-responsive prostatic cancer cell line, LNCaP. Endocrinology 137 991-999. 
Lubahn DB, Josef DR, Sullivan PM, Willard HF, French FS \& Wilson EM 1988 Cloning of human androgen receptor complementary DNA and localization to the X chromosome. Science 240 327-330.

Mooradian AD, Morley JE \& Korenman SG 1987 Biological actions of androgens. Endocrine Revue 8 1-28.

Rifka SM, Cutler JB, Sauer MA \& Loriaux DL 1978 Rat adrenal androgen receptor: a possible mediator of androgen-induced decrease in rat adrenal weight. Endocrinology 103 1103-1110.

Rossi R, Franceschetti P, Maestri I, Magri E, Cavazzini L, degli Uberti EC \& del Senno L 1996 a Evidence for androgen receptor gene expression in human thyroid cells and tumors. Journal of Endocrinology 148 77-85.

Rossi R, Zatelli MC, Franceschetti P, Maestri I, Magri E, Aguiari G, Cavazzini P, degli Uberti EC \& del Senno L 1996 b Inhibitory effect of dihydrotestosterone on human thyroid cell growth. Journal of Endocrinology 151 185-194.

Ruizeveld de Winter JA, Trapman J, Vermey M, Mulder E, Zegers ND \& Van der Kwast TH 1991 Androgen receptor expression in human tissues: an immunohistochemical study. Journal of Histochemistry and Cytochemistry 39 927-936.

Sambrook J, Fritish ET, Maniatis F 1989 Molecular Cloning, A Laboratory Manual. Cold Spring Harbor: Cold Spring Harbor Laboratory Press.

Sar M, Lubahn DB, French FS \& Wilson EM 1990 Immunohistochemical localization of the androgen receptor in rat and human tissues. Endocrinology 127 3180-3186.
Schuurmans AL, Bolt J, Voorhorst MM, Blankenstein RA \& Mulder E 1988 Regulation of growth and epidermal growth factor receptor levels of $\mathrm{LNCaP}$ prostate tumor cells by different steroids. International Journal of Cancer 42 917-922.

Szelei J, Jimenez J, Soto AM, Luizzi MF \& Sonnenschein C 1997 Androgen-induced inhibition of proliferation in human breast cancer MCF7 cells transfected with androgen receptor. Endocrinology 138 1406-1412.

Toscano V, Caiola S, Maroder M, Adamo MV, Argiolas L, Familiari A \& Familiari G 1990 Effects of dihydrotestosterone treatment on adrenal gland function and morphology in adult female guinea-pigs. Journal of Steroid Biochemistry 36 89-97.

degli Uberti EC, Hanau S, Rossi R, Piva R, Margutti A, Trasforini G, Pansini GC \& del Senno L 1991 Somatostatin reduces ${ }^{3} \mathrm{H}$-thymidine incorporation and c-myc, but not thyroglobulin ribonucleic acid levels in human thyroid follicular cells in vitro. Journal of Clinical Endocrinology and Metabolism 72 1364-1371.

Wolf DA, Schulz P \& Fittler F 1991 Synthetic androgens suppress the transformed phenotype in the human prostate carcinoma cell line LNCaP. British Journal of Cancer 64 47-53.

Wong CI, Zhou ZX, Sar M \& Wilson EM 1993 Steroid requirement for androgen receptor dimerization and DNA binding. Journal of Biological Chemistry 268 19004-19012.

Received 19 December 1997

Revised manuscript received 28 April 1998

Accepted 13 July 1998 